\title{
DESIGN AND CONSTRUCTION OF FOOTINGS OF BUILDINGS AND STRUCTURES ON PERMAFROST SOILS IN CONJUNCTION WITH ENVIRONMENTAL REQUIREMENTS
}

\author{
Igor I. Sakharov ${ }^{1}$, Nadezda S. Nikitina ${ }^{2}$, S. Nyamdorzh ${ }^{3}$, E.S. Shin ${ }^{4}$ \\ ${ }^{1}$ Saint-Petersburg State Architecture and Construction University, Saint-Petersburg, RUSSIA \\ ${ }^{2}$ National Research Moscow State University of Civil Engineering, Moscow, RUSSIA \\ ${ }^{3}$ Mongolian University of Science and Technology, Ulaanbaatar, MONGOLIA \\ ${ }^{4}$ University of Incheon, Republic of Korea, Incheon, SOUTH KOREA
}

\begin{abstract}
The article describes features of design and construction of footings of buildings and structures on permafrost soils. Examples of failures of objects were given. It was shown that the available calculation tools, in particular the "Termoground" program, allow to estimate many situations connected not only with temperature problems, but also with the stress-strain state of the "base - structure system". This allows carrying out design of arbitrary objects operating without failures during a long time. Consequently, the impact of such objects to ecology of surrounded environment is minimum.
\end{abstract}

Keywords: experimental studies, permafrost, freezing, thawing, bearing capacity, frost heaving

\section{ПРОЕКТИРОВАНИЕ И СТРОИТЕЛЬСТВО ФУНДАМЕНТОВ ЗДАНИЙ И СООРУЖЕНИЙ НА ВЕЧНОМЕРЗЛЫХ ГРУНТАХ В УВЯЗКЕ С ТРЕБОВАНИЯМИ ЭКОЛОГИИ}

\author{
И.И. Сахаров ${ }^{1}$, Н.С. Никитина ${ }^{2}$, С. Нямдоржс ${ }^{3}$, Е.С. Шин ${ }^{4}$ \\ ${ }^{1}$ Санкт-Петербургский государственный архитектурно-строительный университет, \\ г. Санкт-Петербург, РОССИЯ \\ ${ }^{2}$ Национальный исследовательский Московский государственный строительный университет, \\ г. Москва, РОССИЯ \\ ${ }^{3}$ Mongolian University of Science and Technology, Улан-Батор, МОНГОЛИЯ \\ ${ }^{4}$ University of Incheon, Republic of Korea, Город, Инчеон, ЮЖНАЯ КОРЕЯ
}

\begin{abstract}
Аннотация: В статье рассматриваются особенности проектирования и строительства фундаментов зданий и сооружений на вечномерзлых грунтах. Приведены примеры аварий объектов. Показано, что имеющиеся расчетные средства, в частности программа «Termoground», позволяют оценивать многие ситуации, связанные не только с температурными задачами, но и с напряженно-деформированным состоянием системы «основание - сооружение». Это позволяет осуществлять проектирование любых объектов, эксплуатирующихся безаварийно в течение длительного времени, что оказывает минимальную нагрузку на экологию окружающей среды.
\end{abstract}

Ключевые слова: экспериментальные исследования, вечномерзлый грунт, промерзание, оттаивание, морозное пучение, несущая способность

The construction of buildings and structures of any purpose on permafrost soils presents great difficulties. Objects in some cases are deformed, and sometimes accidents also happen. In addition, construction in northern conditions often 
causes damage to the environment and, thus, negatively affects the environment.

The greatest damage to the frozen state of the base is caused by its heating. So, the heat spreading from heated buildings penetrates the frozen ground, which causes its degradation due to thawing. Oil and gas pipelines for any purpose at a temperature of the transported product from 25 to $60^{\circ} \mathrm{C}$ also cause thawing of the surrounding soil. Railways and roads transfer heat to the base, transferred by filtered water through the embankment, as well as heat caused by the action of the transport vibrodynamic load. Some noted problems are illustrated in Figures 1, 2, 3, 4 .

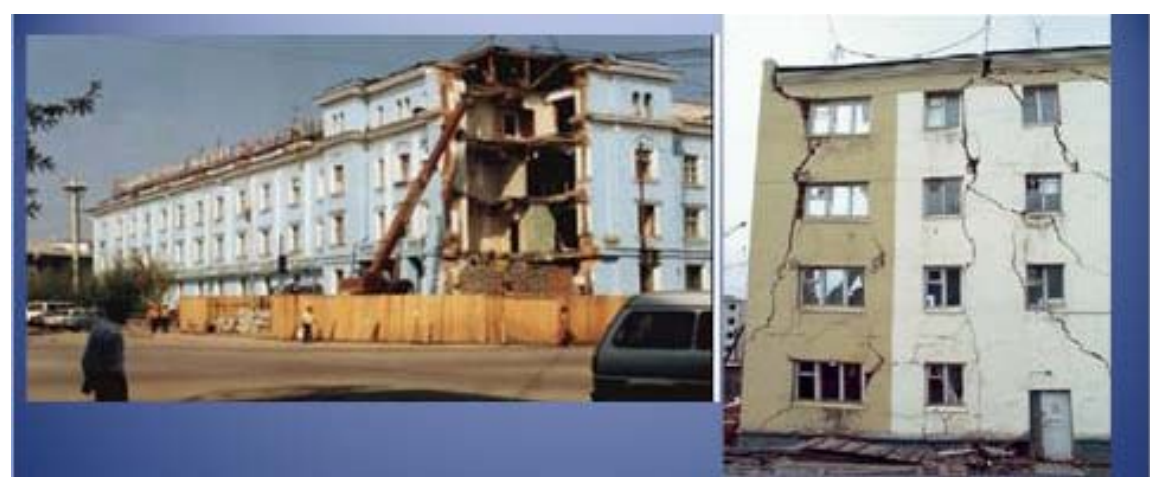

Figure 1. Failure of parts of buildings constructed on permafrost soils when ice of permafrost soils thaw.

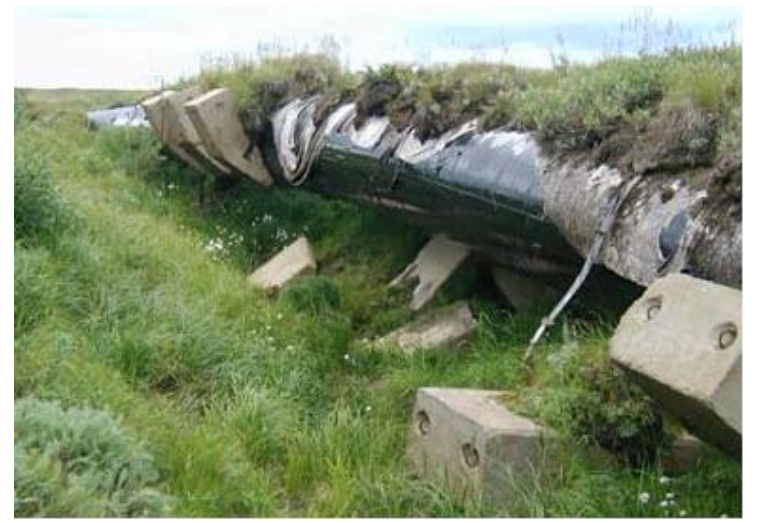

Figure 2. Failure of pipeline due to thawing of the foundation.

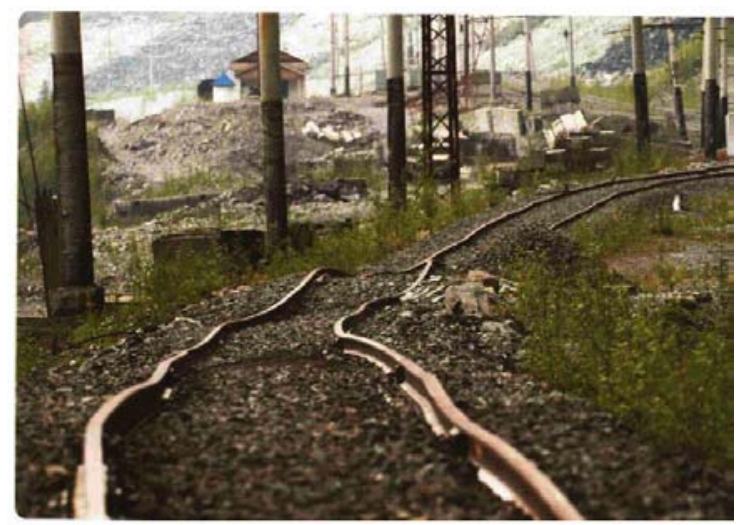

Figure 3. Bending of railway caused by thawing of the foundation.

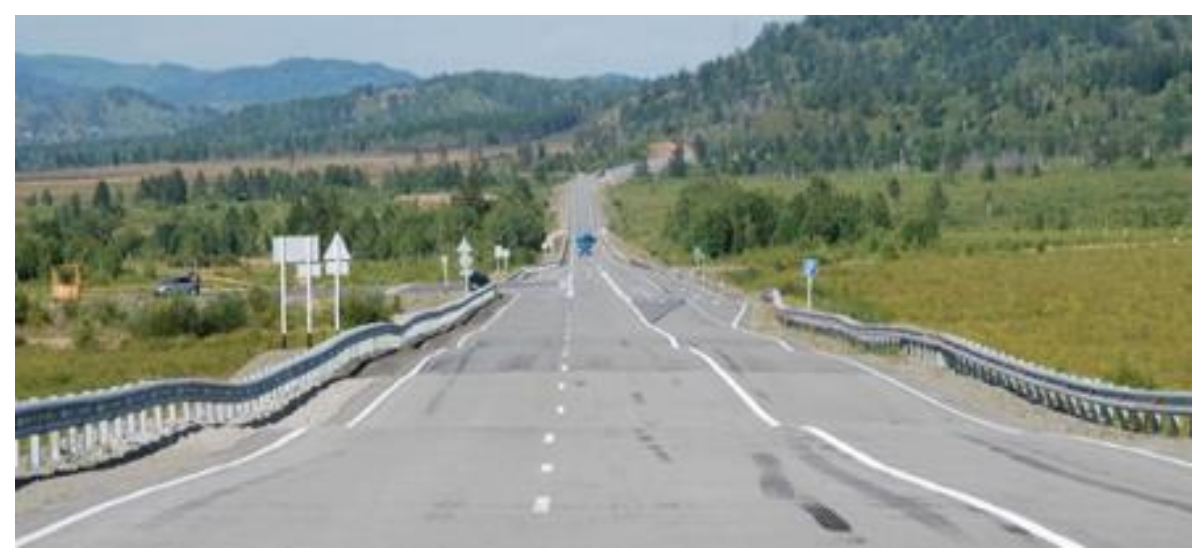

Figure 4. Subsidence of the roadway when the foundation thaw locally. 
Design and Construction of Footings of Buildings and Structures on Permafrost Soils in Conjunction With Environmental Requirements

The successful construction of buildings and structures on permafrost soils in accordance with applicable standards is ensured by the implementation of one of two principles - with conservation (principle I) and without conservation (principle II) of the frozen state of the base. For heated buildings, principle I is most often used. The most rational in this case is the installation of a ventilated underground (Figures 5, 6). This method is widely used in the North of Russia and in a number of cases gives good results. However, the underground is ineffective with a high height of snow, which has a warming effect on the base. In addition, when building on high-temperature soils, the underground device should be preceded by preliminary cooling of the base.

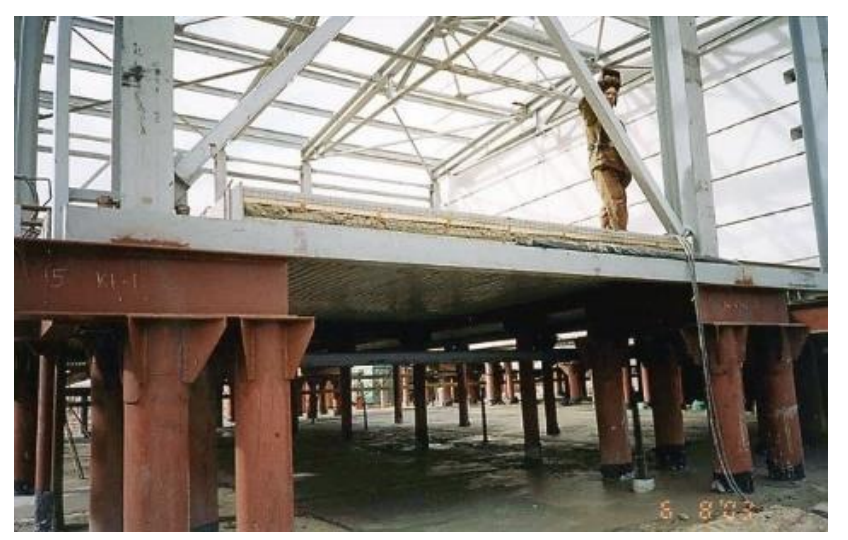

Figure 5. Construction of ventilated underground on metal piles.

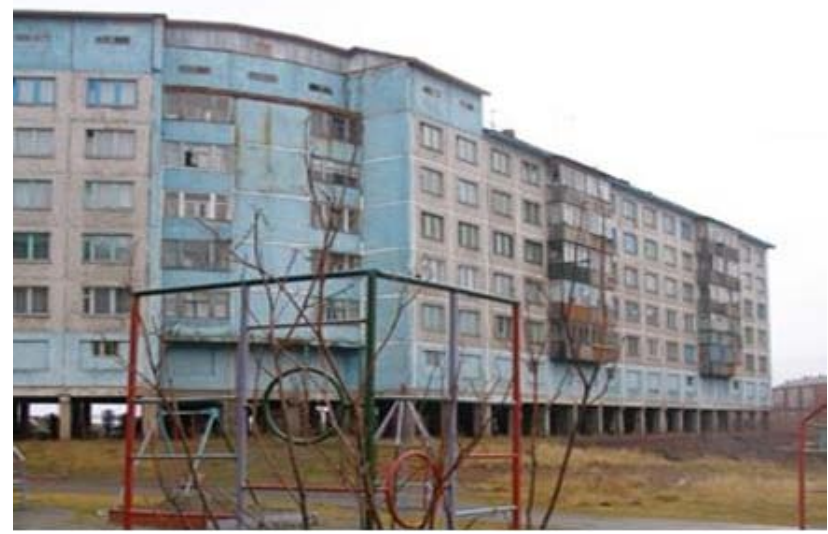

Figure 6. Construction of ventilated underground on reinforced concrete piles.

Principle II, being significantly cheaper, is often used for linear structures such as embankments of railways and roads. For the Baikal-Amur Railway (BAR), whose length in the zone of high-temperature permafrost is about $2000 \mathrm{~km}$, this principle is fundamental. However, the practice of exploitation of BAR has shown that further use of principle II is ineffective. Permafrost degradation occurs at the base of the embankments, which is accompanied by precipitation reaching $20 \mathrm{~cm} /$ year. Thawing processes at the base of one of the BAR mounds are shown in Figures 7-9.

Deformations of the railways lead to work on their repair and straightening. In addition to annual costs, repair work has a negative impact on the environment. At the same time, the passageways of the equipment are accompanied by damage to the natural thermal insulation - the moss carpet, which leads to complete degradation of the territory (Figure 10). Thus, attempts to use the cheaper principle II often leads to accidents of objects and degradation of frozen soils not only at the construction site, but at a considerable distance from it.

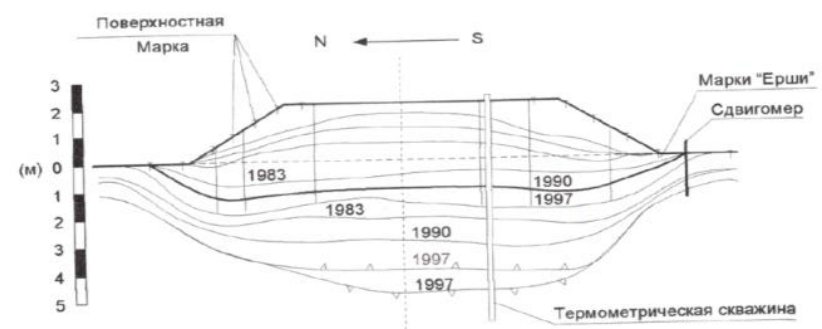

Figure 7. Dynamic of thawing process in the one of the BAR mounds. Numbers on isolines corresponds to years.

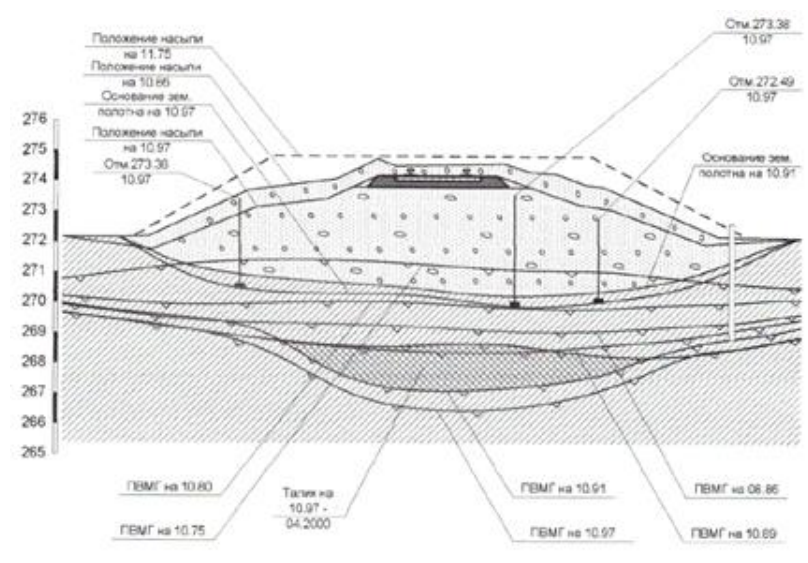

Figure 8. The dynamics of thawing of the base with the formation of talik (shaded area). 


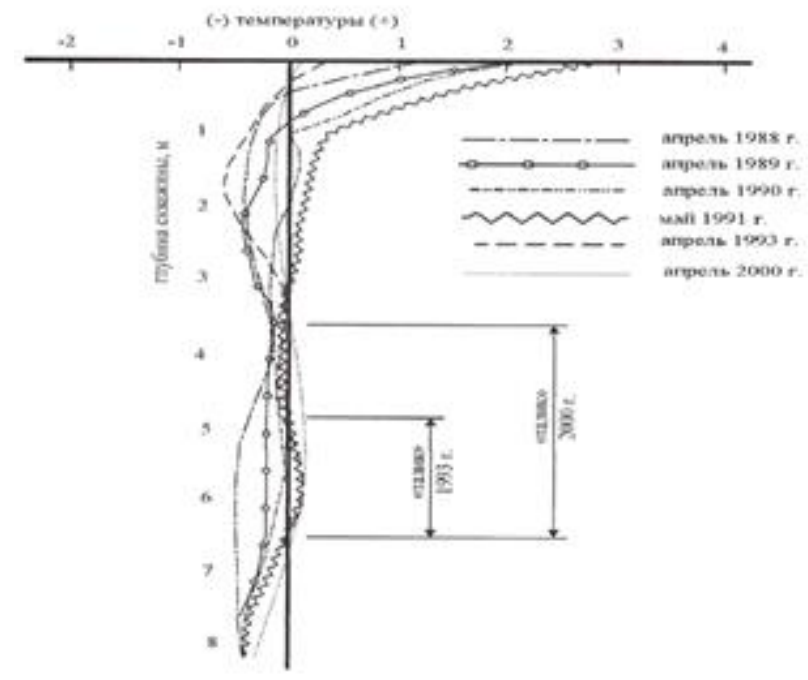

Figure 9. Graphs of temperature measured in the well. The formation of talik not freezing in the annual cycle. Numbers on isolines corresponds to years.

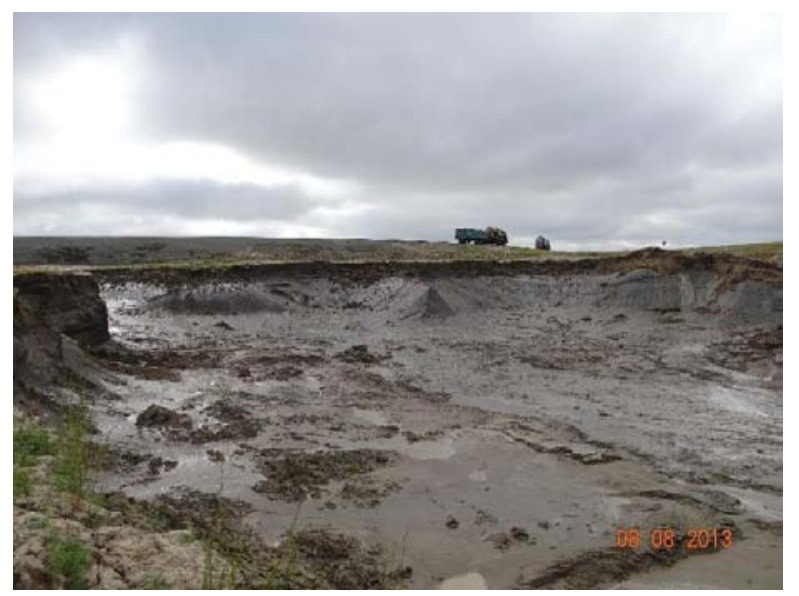

Figure 10. Degradation of frozen soils when moss carpet is damaged

In connection with the aforementioned facts, in order to minimize the influence of buildings and structures on the surrounding Arctic environment, it is necessary to build so that the object retains its operational properties without repairs for many years. For buildings, this is usually achieved using principle I, implemented with the help of modern cooling systems, and first of all, seasonal cooling devices (SCD) (Figure 11). Relatively more rarely are thermo supports used primarily for bridges or pipelines (Figures 12, $13)$.

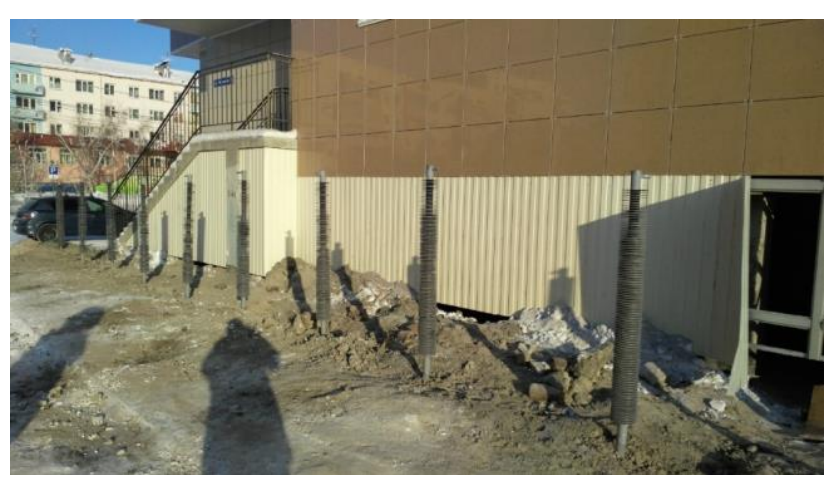

Figure 11. The location of the capacitor parts of the SCD at the wall of the building.

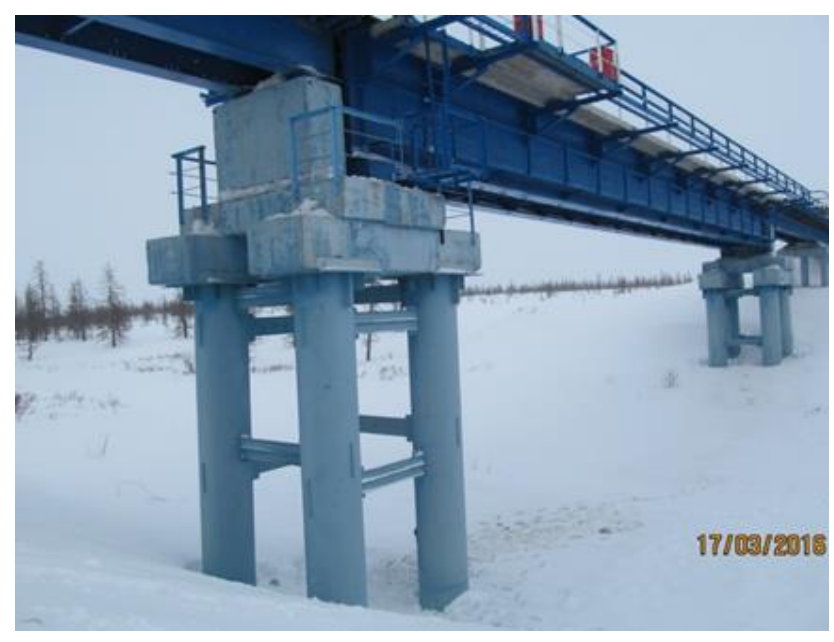

Figure 12. Bridge support on stilts with natural air cooling (thermal supports).

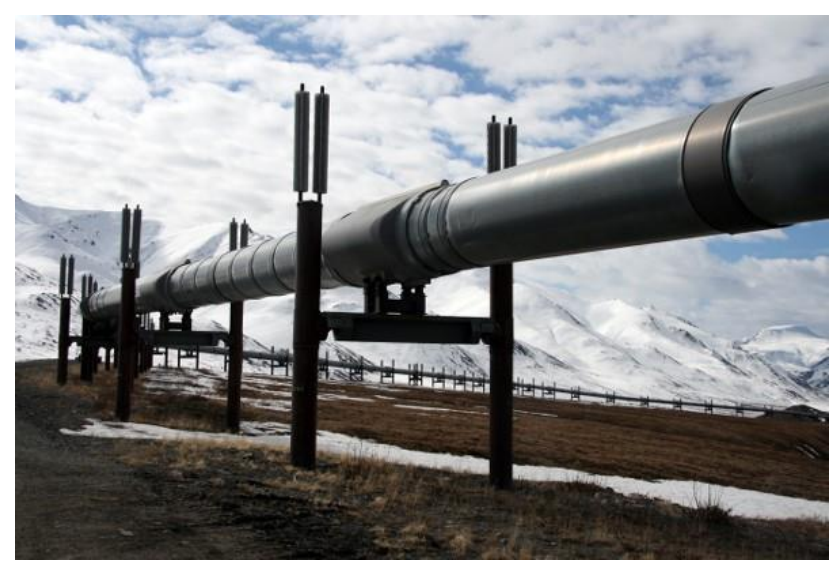

Figure 13. Oil pipeline on stilts equipped with SCD.

If principle II is used in construction, then a gap should usually be provided between the sole of the structure and the base, while pile or post 
supports should be buried in frozen ground, substantially greater than the depth of the expected thawing. For highways, in this case, overpasses will be effective, which will bring the speed to $300 \mathrm{~km} / \mathrm{h}$. In this case, the influence of objects on the environment will be minimal (Figures 14, 15).

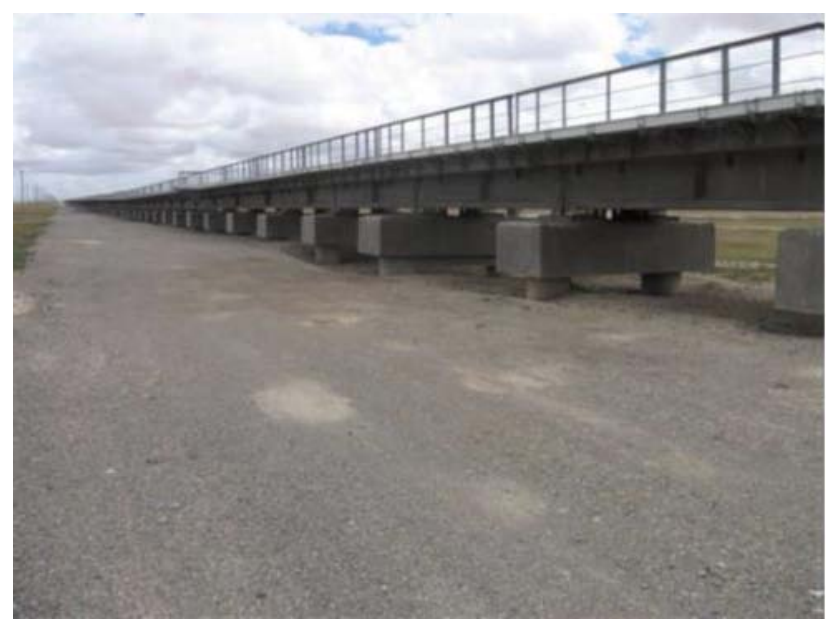

Figure 14. The device of the railway track on the low overpass.

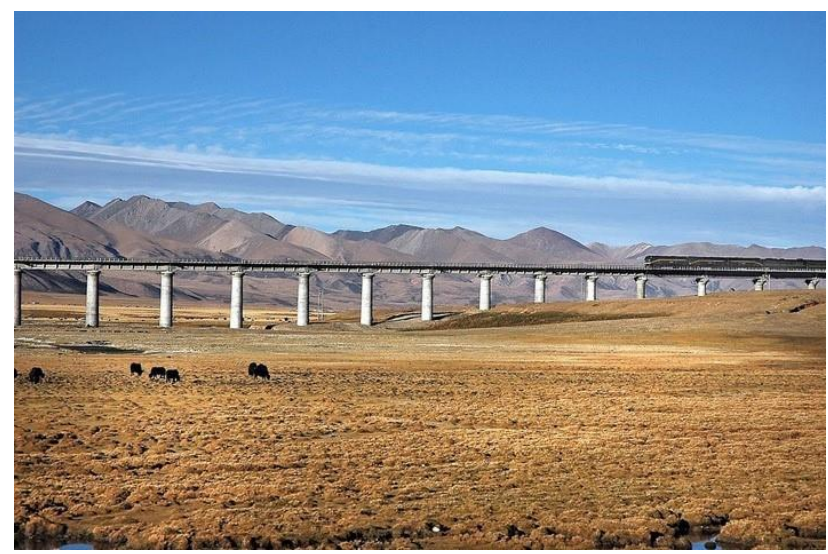

Figure 15. Arrangement of the railway track on a high overpass

Note that the arrangement of roads on overpasses has a number of advantages. Among them, simplicity of design due to specific extremely stringent requirements for maximum precipitation $(20-30 \mathrm{~mm})$ and profile fracture angle $\left(1^{\circ}\right.$ $\left./{ }^{\circ}\right)$ [1,2], which forces designers to resort to powerful, relatively deeply laid supports. The construction of overpasses allows you to abandon the large volume of inert materials deliv- ered from quarries on temporary roads. In addition, overpasses practically do not affect the environmental situation and, with proper design and construction, guarantee the road's maintenance-free existence for many years.

The design support for the construction of footings on permafrost soils should primarily include an assessment of the temperature fields in the base. Due to the layering of the base, the frequent presence of thermal insulation, etc. effective temperature calculations can be performed only by numerical methods. There are many programs that allow you to evaluate temperature fields. However, when calculating temperatures in freezing or thawing clay soils, it is necessary to take into account that, due to the large amount of non-freezing bound water, phase transitions occur in the so-called "negative temperature spectrum", which leads to significant computational difficulties. However, the greatest difficulty is the assessment of deformations initiated by freezing and thawing processes. At the same time, if thawing strains can be relatively easily calculated using the two-term norm formula (Lapkin - Tsytovich), then defining frost heaving strains is a difficult task.

In order to establish deformations of frost heaving, the calculation method proposed in [3] may turn out to be quite effective. The method allows you to set all the components of frost heaving deformation, as well as tangential and normal forces. Based on the "Termoground" program [4], the proposed method allows, in addition to deformations of raising and lowering, to evaluate the stability of structures against the action of tangential forces of frost heaving. In the case of thawing, the "Termoground" program quite simply allows you to set the negative friction forces acting, for example, on piles or pillars.

Below Figure 16 shows a number of examples of calculations of temperature fields around a single SCD (Figure 16) and groups of SCD at the base of a building (Figure 17).

Figure 18 shows the lifting deformations of the building frame elements under the action of frost heaving forces. Figure 19 shows the effect of negative friction on the pile foundation of a building with possible thawing of the base. 


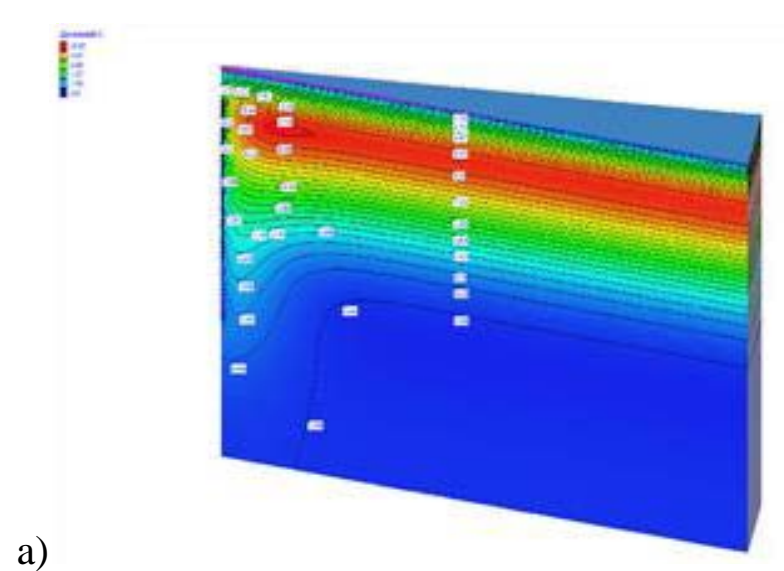

b)

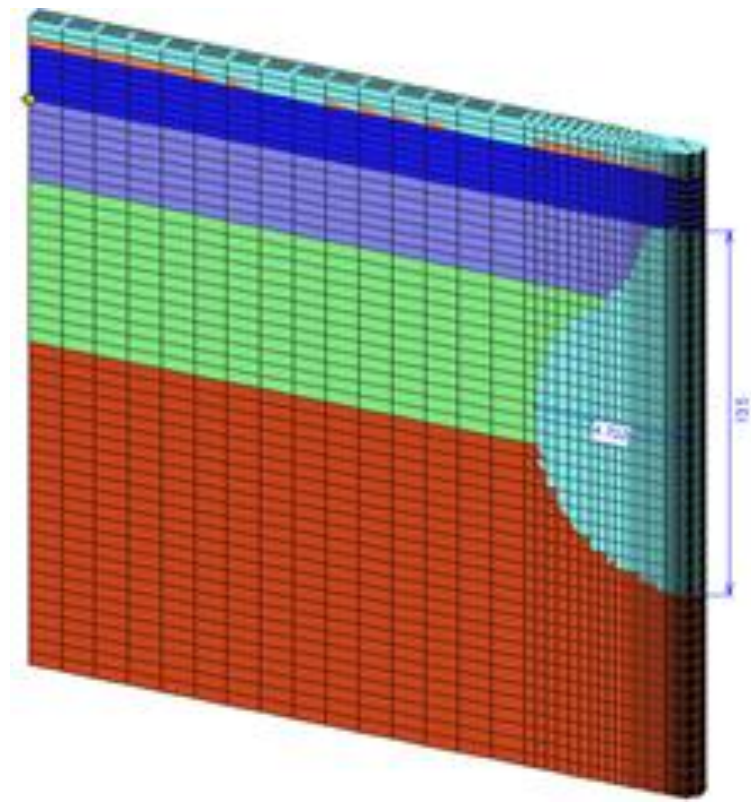

Figure 16. Temperature contours (a) and contours of the frozen ground zone (b) around a single SCD.

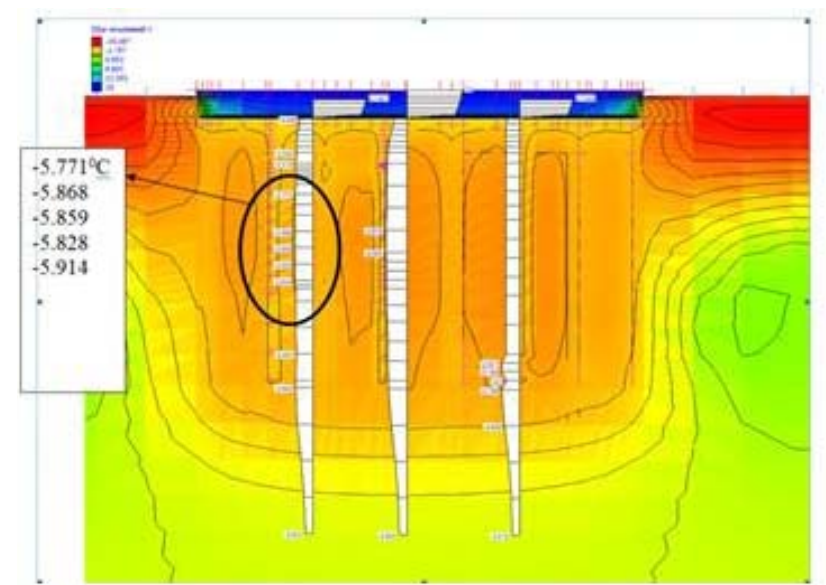

Figure 17. Temperature plots in the base, cooled by group SCD (horizontal and vertical).

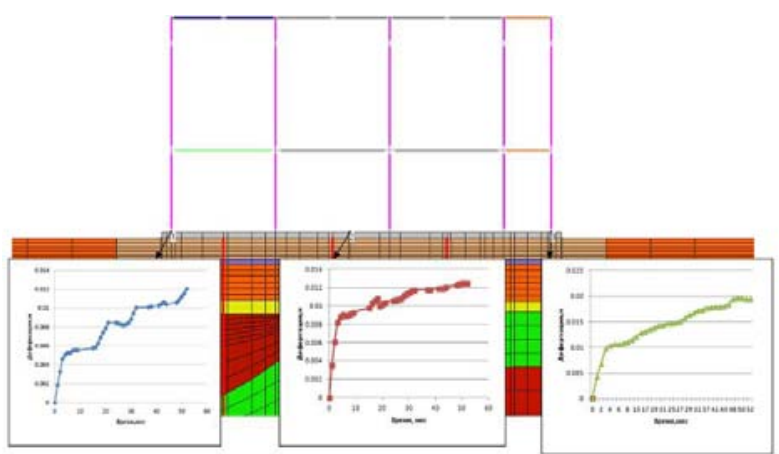

Figure 18. Lift deformations of building frame elements under the action of frost heaving forces.

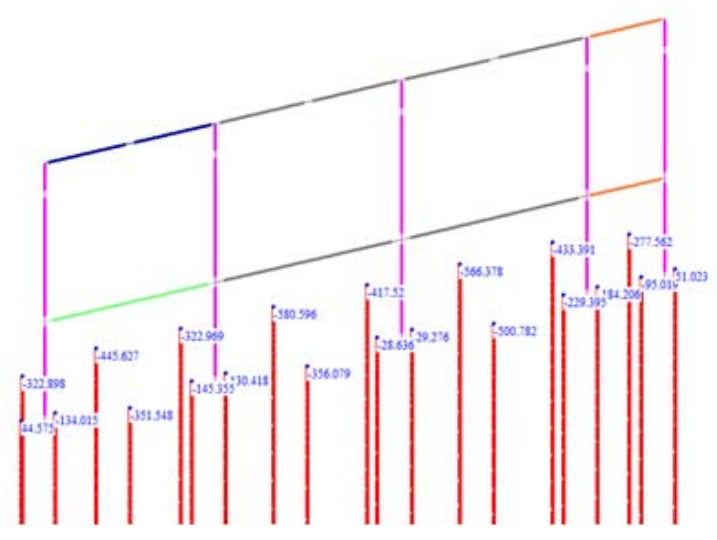

Figure 19. Increased loads on piles with negative friction caused by possible thawing.

Thus, the available settlement tools allow you to implement a fairly reliable and durable design solutions. This allows the construction of buildings and structures, trouble-free operation of which is possible for a long time. This approach minimizes the environmental impact of the construction and operation of buildings and structures, which is important in light of stricter environmental requirements, especially relevant in the northern regions.

\section{REFERENCES}

1. California High-Speed Train Project: Design Criteria: Book 3, Part C, Subpart 1. California High-Speed Rail Authority. Sacramento: California High-Speed Rail Authority Publ., 2012, 1279 pages. 
Design and Construction of Footings of Buildings and Structures on Permafrost Soils in Conjunction With Environmental Requirements

2. Code for Design of High-Speed Railway: Professional standard of the People's Republic of China: (Trial)/Ministry of Railways of the PRC. Beijing: China Railway Publishing House, 2010, 217 pages.

3. Sakharov I.I. Computational method for soil frost heaving characteristics determination. // Proceedings of the international conference on geotechnics fundamenals ... (grac 2019), Saint Petersburg, Russia, 6-8 February 2019. Geotechnics Fundamentals and Applications in Construction: New Materials, Structures, Technologies and Calculations. Volume 2 CRC Press/Balkema 2019, pp. 307-312.

4. Ulitskii V.M. Sakharov I.I., Paramonov V.N., Kudryavtsev S.A. Bed - Structure System Analysis for Soil Freezing and Thawing Using the Termoground Program. // Soil Mechanics and Foundation Engineering, 2014, No. 52(5), pp. 240-246.

\section{СПИСОК ЛИТЕРАТУРЫ}

1. California High-Speed Train Project: Design Criteria: Book 3, Part C, Subpart 1. California High-Speed Rail Authority. Sacramento: California High-Speed Rail Authority Publ., 2012, 1279 pages.

2. Code for Design of High-Speed Railway: Professional standard of the People's Republic of China: (Trial)/Ministry of Railways of the PRC. Beijing: China Railway Publishing House, 2010, 217 pages

3. Sakharov I.I. Computational method for soil frost heaving characteristics determination. // Proceedings of the international conference on geotechnics fundamenals ... (grac 2019), Saint Petersburg, Russia, 6-8 February 2019. Geotechnics Fundamentals and Applications in Construction: New Materials, Structures, Technologies and Calculations. Volume 2 CRC Press/Balkema 2019, pp. 307-312.

4. Улицкий В.М., Сахаров И.И., Парамонов В.Н., Кудрявцев С.А. Расчет системы «основание - сооружение» при промерзании и оттаивании грунтов с помощью программы «Termoground». //
Основания, фундаменть и механика грунтов, 2015, №5.

Сахаров Игорь Игоревич, доктор технических наук, профессор кафедры геотехники СанктПетербургского государственного архитектурностроительного университета; г. Санкт-Петербург, Россия, 198005, 2-я Красноармейская ул., д. 4, тел./ факс +7(812) 316-03-41;

E-mail: i.sakharov2014@yandex.ru.

Никитина Надежда Сергеевна, старший научный сотрудник кафедры «Механики грунтов и геотехники» Московский государственный строительный университет, г. Москва, Россия, 129337, Ярославское шоссе, д.26,тел./факс: +7(495) 287-49-14,

E-mail: nsnikitina@mail.ru.

Тугчин Нямдорж Сетев, Ph.D, профессор кафедры «Промышленно-гражданского строительства» Монгольского государственного университета науки и технологии. г.Уланбатор, Монголия 14191, Бага тойруу-34.Тел/факс: +(976-11) 323619;

E-mail: nyamdorj999@yahoo.com.

Ёон Чул Шин,Ph.D, профессор кафедры «Инженеринга гражданского строительства и окружающей среды» Национального университета Инчеона. г. Инчеон 22012, Южная Корея, 119 Академия-ро, Сонгдо-дон, Иеонсу-гу. Тел: +82-32-835-8466,

E-mail: ecshin@inu.ac.kr.

Igor Igorevich Sakharov, PhD CEng. Doctor of Science and Technology, professor, Department of Geotechnial, St-Petersburg State University of Civil Engineering, 4, 2Krasnoarmeiskaya str. Saint-Petersburg, 198005, Russia, phone/fax: +7(812) 316-03-41

E-mail: i.sakharov2014@yandex.ru

Nadezda Sergeevna. Nikitina, PhD, Department of "Soil Mechanics and Geotechnical", Moscow State University of Civil Engineering (National Research University), 26, Yaroslavskoe Shosse, Moscow, 129337, Russia; phone/fax: +7(495) 287-49-14;

E-mail: nsnikitina@mail.ru.

Nyamdorj Setev Tugchin, Ph.D, professor Department "Civil engineering" of Mongolian State University of Science and Technology. Ulaanbaatar 14191 .Mongolia, Bagatoiruu-34, phone/fax: $+(976-11) 323619$;

E-mail: nyamdorj_999@yahoo.com.

Eun Chul Shin Ph.D, professor Department "Civil and Environmental engineering" Incheon National University, 119 Academy-ro. Songdo-dong. Yeonsu-gu. Incheon. 22012. Respublic of Korea; phone/fax:+82-32-835-8466; E-mail: ecshin@inu.ac.kr. 